\title{
The role of Sevista (ormeloxifene) in the management of dysfunctional uterine bleeding
}

\author{
Nikita Gandotra $^{1}$, Preeti Sharma ${ }^{1}$, Abhinav Sharma ${ }^{2}$, Syed Masuma Rizvi ${ }^{1}$ \\ ${ }^{1}$ Department of Obstetrics and Gynaecology, LD Hospital, Srinagar, Jammu and Kashmir, India \\ ${ }^{2}$ Department of Pulmonary Medicine, NH Hospital, Jammu, India \\ Received: 30 October 2016 \\ Revised: 05 November 2016 \\ Accepted: 30 November 2016

\section{*Correspondence:} \\ Dr. Nikita Gandotra, \\ E-mail: nikigandotra@gmail.com \\ Copyright: (c) the author(s), publisher and licensee Medip Academy. This is an open-access article distributed under \\ the terms of the Creative Commons Attribution Non-Commercial License, which permits unrestricted non-commercial \\ use, distribution, and reproduction in any medium, provided the original work is properly cited.
}

\begin{abstract}
Background: Dysfunctional uterine bleeding (DUB) is a common gynaecological disorder that usually ends up in hysterectomy and causes psychological and physiological stress. Medical management with hormones and NSAIDS has inherited side effects. Ormeloxifene, a selective estrogen receptor modulator, is emerging as a safe and effective agent for dysfunctional uterine bleeding. The objective of the study was to evaluate the role of ormeloxifene in medical management of dysfunctional uterine bleeding.

Methods: 30 patients, on whom diagnosis of dysfunctional uterine bleeding was made, were included in the study. Patients were given ormeloxifene $60 \mathrm{mg}$ twice a week for 12 weeks and then once a week for 12 weeks. The primary outcome measures were menstrual blood loss (assessed by pictorial blood assessment chart score), hemoglobin concentration and endometrial thickness. The secondary outcome measures were acceptability and side effects of ormeloxifene.

Results: There was a significant reduction in mean PBAC score from 316 to 52 after six months of treatment. The mean hemoglobin concentration increased significantly from 8.4 to $9.8 \mathrm{gms} / \mathrm{dl}$ with a rise of $1.4 \mathrm{gm} / \mathrm{dl}$ (p $<0.05)$. The mean pretreatment endometrial thickness was $10.8 \mathrm{~mm}$ and it decreased significantly to $8.1 \mathrm{~mm}$ after 6 months of treatment with ormeloxifene $(\mathrm{p}<0.05) .76 .7 \%$ of the women showed marked subjective improvement in symptoms. The most common side effect reported was amenorrhea (13.3\%).

Conclusions: Ormeloxifene can be considered as an effective and safe therapeutic option for the medical management of dysfunctional uterine bleeding.
\end{abstract}

Keywords: DUB, Dysfunctional uterine bleeding, Ormeloxifene, SERM

\section{INTRODUCTION}

Dysfunctional Uterine Bleeding (DUB) is a state of abnormal uterine bleeding without any clinically detectable organic, systemic and iatrogenic cause. It is the most common menstrual disorder of women in reproductive age and is a diagnosis of exclusion. ${ }^{1}$

DUB is a diagnosis that does not apply to menorrhagia only, but also includes excessively prolonged and frequent bleeding (Menometrorrhagia). It occurs more frequently in anovulatory than ovulatory cycles. ${ }^{2}$
Dysfunctional uterine bleeding is a common debilitating problem among women in all age groups and accounts for $20 \%$ of gynaecology office visits. ${ }^{3}$ Treatment modalities are available which include medical therapy and surgical interventions. Pharmacological management can be hormonal or non-hormonal. Hormonal agents include oestrogens, progesterones, combination of the two, androgens, danazol, GnRH agonists and the latest SERMS (Selective Oestrogen Receptor Modulators). Non-hormonal drugs like NSAIDs, ethamsylate and antifibrinolytics have also been found to be highly effective. Medical management has always been the first 
therapeutic option to be tried and if it fails to show results, one can resort to surgical interventions.

Hysterectomy should be the last resort in the management of DUB. Because of the morbidity associated with the surgical procedures, the RCOG recommends beginning with medical management before resorting to surgical interventions. ${ }^{4}$ Medical treatment of menorrhagia should aim to relieve symptoms, improve quality of life and avoid the risk of surgery.

Ormeloxifene is a third generation benzopyran SERM which blocks the cytosol receptors by its competitive binding and selectively acts on estrogen receptors as agonist and antagonist in different reproductive tissues. It has anti-estrogenic action on endometrium and breast and estrogenic action on bones, vagina, liver, cardiovascular and central nervous system.

The ideal therapy in perimenopausal women is one that has no uterine stimulation, prevents bone loss, has no risk of breast cancer, has a positive effect on lipids and cardiovascular system and maintains cognitive function of brain. It is best known as a non-hormonal, nonsteroidal oral contraceptive which is taken once per week. $^{5}$

It causes an asynchrony in the menstrual cycle between the ovulation and the development of the uterine lining, although its exact mode of action has not been well defined. In clinical trials, it caused the ovulation to occur later than it normally would, in some women but did not affect the ovulation in majority of the women, while causing the lining of the uterus to build more slowly. It speeds the transport of any fertilized egg through the fallopian tubes more quickly, than is normal .Presumably; this combination of effects creates such an environment that if fertilization occurs, an implantation will not be possible. $^{6}$

Table 1: PBAC score.

\begin{tabular}{|lll|}
\hline \multirow{4}{*}{ Pads } & Level of soiling & Score \\
\cline { 2 - 3 } & Light & 1 \\
\cline { 2 - 3 } & Moderate & 5 \\
\cline { 2 - 3 } & Saturated & 20 \\
\hline \multirow{2}{*}{ Clots } & Size of a rupee, coin or smaller 1 \\
\cline { 2 - 3 } & Larger than a rupee ,coin & 5 \\
\hline
\end{tabular}

\section{METHODS}

This descriptive study was conducted in Lalla Ded hospital, Government Medical College, Srinagar on patients attending out patients' clinic over a period of one year. 30 women presenting with abnormal uterine bleeding without any organic, systemic or iatrogenic cause were included in the study. A detailed history was taken and thorough clinical examination was done. The investigations which were carried out included complete blood count, coagulation profile, thyroid profile, blood sugar, liver function test, kidney function test, ultrasound of the abdomen and pelvis and endometrial thickness measurement.

Exclusion criteria were pelvic pathologies like uterine fibroid, endometriosis, malignancies of genital tract, medical disease like liver dysfunction, heart disease, coagulopathies, renal disease, pregnancy, IUCD or pill users, lactating women in the first 6 months of postnatal period, thyroid disorder, history of abortion within last 3 months and hypersensitivity to drug.

Written informed consent was taken from all the patients selected for study. All patients were given tablet ormeloxifene $60 \mathrm{mg}$ twice a week and then once a week for next 12 weeks. Patients were asked to maintain menstrual calendar and were called at monthly interval. At each visit, a detailed menstrual history was taken and physical examination was done. Pictorial blood loss assessment chart (PBAC) was used to measure the menstrual blood loss (MBL). The women were asked to use certain sanitary napkins which have similar absorbent capacities. They recorded the number of napkins used each day and the degree of soiling of each pad used. Number and sizes of clots passed were also noted. Scores were assigned to different degrees of soiling of sanitary napkins and number and size of clots passed. A PBAC score of greater than or equal to 100 was considered diagnostic of menorrhagia. The main outcome measures were MBL, passage of clots, blood hemoglobin $(\mathrm{Hb})$ level and endometrial thickness (ET) in proliferative phase by TVS. Haemoglobin estimation and endometrial thickness was measured at start of therapy and after 6 months of treatment. Subjective improvement and any side effects experienced by patients were noted.

\section{RESULTS}

30 women with the diagnosis of DUB were included in the present study. The mean age of patients was 34 years with a range of 21-50 years. The mean parity was 3 and the mean duration of symptoms was 9.4 months (5-22 months range).

Table 2: Clinical profile of patients.

\begin{tabular}{|lll|}
\hline $\begin{array}{l}\text { Clinical } \\
\text { profile of } \\
\text { patients }\end{array}$ & Clinical parameter & $\begin{array}{l}\text { Mean } \\
\text { (range) }\end{array}$ \\
\hline \multirow{2}{*}{$\begin{array}{l}\text { Age } \\
2\end{array}$} & Parity & $\begin{array}{l}34 \text { years } \\
(21-50 \\
\text { years) }\end{array}$ \\
\hline 3 & $\begin{array}{l}\text { Duration of symptoms in } \\
\text { months }\end{array}$ & $\begin{array}{l}9(1-6) \\
\text { months } \\
(5-22)\end{array}$ \\
\hline
\end{tabular}

Menstrual blood loss was assessed by PBAC and calculated at beginning, then at 3 months and at 6 months 
of treatment. The median pre-treatment PBAC score was 316 and reduced to 52 at six months $(\mathrm{P}<0.05)$.

The mean hemoglobin of the patients at the start of treatment was $8.4 \mathrm{~g} / \mathrm{dl}$. After six month, the mean HB was $9.8 \mathrm{~g} / \mathrm{dl}$. There was a significant increase in mean $\mathrm{HB}$ concentration with a rise of $1.4 \mathrm{~g} / \mathrm{dl}$ after 6 months of therapy with ormeloxifene $(\mathrm{P}<0.05)$.

The pre and post treatment endometrial thickness was $10.8 \mathrm{~mm}$ and $8.1 \mathrm{~mm}$ respectively with a significant decrease of $2.7 \mathrm{~mm}(\mathrm{P}<0.05)$.

Table 3: Outcome of the study after 6 months.

\begin{tabular}{|lccc|}
\hline Parameter & $\begin{array}{l}\text { pre } \\
\text { treatment }\end{array}$ & $\begin{array}{l}\text { Post } \\
\text { treatment }\end{array}$ & $\begin{array}{l}\text { P } \\
\text { value }\end{array}$ \\
\hline Mean PBAC & 316 & 52 & $<0.05$ \\
\hline Mean HB(g/dl) & 8.4 & 9.8 & $<0.05$ \\
\hline $\begin{array}{l}\text { Mean } \\
\text { endometrial } \\
\text { thickness }(\mathrm{mm})\end{array}$ & 10.8 & 8.1 & $<0.05$ \\
\hline
\end{tabular}

Subjective improvement in the signs and symptoms of DUB was analysed from patients. 23 patients $(76.7 \%)$ had marked improvement in their symptoms, 4 (13.3\%) patients had mild improvement in their symptoms.1 (3.3\%) patient had aggravation of her symptoms for which her treatment was changed.

Table 4: Subjective assessment of symptoms.

\begin{tabular}{|c|c|c|}
\hline $\begin{array}{l}\text { Subjective } \\
\text { improvement }\end{array}$ & Number & Percentage \\
\hline No improvement & 2 & 6.7 \\
\hline Mild improvement & 4 & 13.3 \\
\hline $\begin{array}{l}\text { Marked } \\
\text { improvement }\end{array}$ & 23 & 76.7 \\
\hline $\begin{array}{l}\text { Aggravation of } \\
\text { symptoms }\end{array}$ & 1 & 3.3 \\
\hline Total & 30 & 100 \\
\hline
\end{tabular}

Amenorrhea was observed in $4(13.3 \%)$ patients and hypomenorrohoea in $2(6.66 \%)$ patients. Mild gastric upset, abdominal pain, nausea was observed in few patients and was not statistically significant.

\section{DISCUSSION}

Medical management has always been the first therapeutic option to be tried and if it fails to show results, one can resort to surgical interventions. Hysterectomy should be the last resort in the management of DUB. The RCOG recommends beginning with medical management before resorting to surgical interventions. While hysterectomy offers an effective cure, it is suitable only for those, who have no further wish to conceive. The procedure involves major surgery with significant postoperative morbidity. ${ }^{7,8}$ Endometrial ablation techniques offer an alternative surgical treatment option with significantly reduced postoperative morbidity. But again may be unsuitable for women wishing to retain their menstrual and reproductive function, moreover this requires technical expertise, which is not routinely available.

The ideal therapy should be a designer drug which can block the action of estrogen on the endometrium but not its beneficial effects on other tissue. Selective estrogen receptor modulators are drugs that act in specific ways at each of the estrogen receptor site in different tissues. ${ }^{9}$ Ormeloxifene is an optimally designed SERM with varied tissue response. It is indicated for the treatment of dysfunctional uterine bleeding at any age. It offers the additional advantage of relief of premenstrual syndrome in peri-menopausal women. However, it is not suitable for women desiring pregnancy in view of its contraceptive property.

Ormeloxifene is very effective in improving all the parameters of blood loss including the number of days of bleeding, number of pads soiled and passage of clots.

In our study, we analysed the efficacy of Ormeloxifene in patients with DUB and our results suggested significant reduction in Mean PBAC score from 316 to $52(\mathrm{p}<0.005)$ which was comparable with the studies conducted by Kriplani et al and Dadich et al. ${ }^{10,11}$

There was a significant rise in mean haemoglobin concentration from 8.4 to $9.8 \mathrm{~g} / \mathrm{dl}$ after six months of treatment with a rise of $1.4 \mathrm{~g} / \mathrm{dl}$. The mean endometrial thickness decreased from $10.8 \mathrm{~mm}$ to $8.1 \mathrm{~mm}$ with 6 months therapy of ormeloxifene and this decrease was found to be statistically significant. Similar to present study, Dhananjay et $\mathrm{al}^{12}$ found a statistically significant increase in hemoglobin concentration $(8.26$ to $10.59 \mathrm{~g} / \mathrm{dl}$, $\mathrm{P}<0.001)$ and a statistically significant decrease in endometrial thickness $(9.83$ to $4.89 ; \mathrm{P}<0.001)$ after 3 months of treatment with ormeloxifene. Biswas et $\mathrm{al}^{13}$ found that the difference between pre-treatment and posttreatment median PBAC score of 97.2 and the rise in mean haemoglobin concentration of $1.3 \mathrm{~g} / \mathrm{dl}$ was statistically significant $(\mathrm{P}<0.001)$.

$76.7 \%$ patients had marked improvement in their symptoms in our study, $6.7 \%$ patients had no improvement. Bhattacharjee found there was marked improvement in $81.67 \%$ cases on ormeloxifene. They found no improvement in $10 \%$ cases on ormeloxifene. ${ }^{14}$ Kriplani et al found eighty-eight percent of cases showed marked subjective improvement with ormeloxifene). ${ }^{10}$ There was no improvement in $6 \%$ cases with ormeloxifene. 


\section{CONCLUSION}

Ormeloxifene was found to be an excellent drug in controlling dysfunctional uterine bleeding without effecting normal endocrinal and physiological parameters. It leads to a significant reduction in menstrual blood loss and a significant decrease in endometrial thickness without any major side effect. Ormeloxifene is suitable for the treatment of DUB, in all age groups with effective therapeutic efficacy and with least side effects. Our study also shows that the compliance of the patient is good because of convenient dosage schedule and no need for medicine intake every day.

\section{ACKNOWLEDGEMENTS}

We are thankful to the patients for their trust and cooperation.

\section{Funding: No funding sources}

Conflict of interest: None declared

Ethical approval: The study was approved by the Institutional Ethics Committee

\section{REFERENCES}

1. Bravender T, Emans SJ. Menstrual disorders. Dysfunctional uterine bleeding. Pediatr Clin North Am. 2015;46(3): 545-53.

2. Hoffman BL, Schorge JO, Schaffer JI, Halvorson M, Bradshaw KD, Gray F (Eds): Abnormal uterine Bleeding. In: Schorge JD editor. Williams Gynaecology, 2nd Ed. New York: McGraw-Hill; 2003. p.219.

3. Frick KD, Clark MA, Steinwachs DM. STOP-DUB Research Group. Financial and quality-of-life burden of dysfunctional uterine bleeding among woman agreeing to obtain surgical treatment. Women's Health Issues. 2009;19(1):70-8.

4. Calvert KL. Review of Second Generation Endometrial Ablation Techniques. Obs and Gynaecol. 2002;VII(2):371-6.

5. Tandon Annu M, Goel I. The effect of ormeloxifene, a selective estrogen receptor modulator, on the biomarkers of the endometrial receptivity and the pinopode development and its relationship with the fertility and the infertility in Indian subjects" Fertility and Sterility. 2009;91(6):2298-307.

6. Singh MM. Centchroman, a selective estrogen receptor modulator, as a contraceptive and for the management of hormone-related clinical disorders. Medicinal Research Reviews. 2001;21(4):302-47.

7. Higham JM, O' Brein PM, Shaw RW. Assessment of menstrual blood loss using a pictorial chart. Br J obstet Gynaecol. 1990;97(8):734-9.

8. Dicker RC, Greenspan JR, and Strauss LT. Complications of abdominal and vaginal hysterectomy among women of reproductive age in the United States. American Journal of Obstetrics and Gynecology. 1982;144:841-8.

9. Preston JT, Cameron IT, Adams EJ, Smith Sk. Comparative study of tranexamic acid and norethisterone in the treatment of ovulatory menorhagia. British J Obstetrics Gynecology. 1995;102:401-86.

10. Kriplani A, Kulshrestha B, Agarwal N. Effeciency and safety of ormeloxifene in management of menarhagia: a pilot study. J Obstet Gynecol Res. 2009;35:746-52.

11. Dadich, S, Agarwal, M.Soni and R. Jain. Role of ormeloxifene in medical management of dysfunctional uterine bleeding. Asian journal of Obs and Gynae Practice. 2012;6:28-31.

12. Dhananjay BS, Nanda SK. Role of sevista in management of uterine bleeding. Journal of clinical diagnostic and Research. 2013;7(1):132-4.

13. Biswas SC, Saha SK. Ormeloxifene, A selective estrogen receptor modulator for treatment of dysfunctional menorhagia. J obstet Gynecol. 2004;54(1):56-9.

14. Anusyua B. Efficacy of a Selective Estrogen Receptor Modulator: 'Ormeloxifene' in Management of Dysfunctional Uterine Bleeding. South Asian Federation of Obstetrics and Gynecology. 2010;2(3):207-11.

Cite this article as: Gandotra N, Sharma P, Sharma A, Rizvi SM. The role of Sevista (ormeloxifene) in the management of dysfunctional uterine bleeding. Int J Reprod Contracept Obstet Gynecol 2017;6:21922. 